https://doi.org/10.46344/JBINO.2021.v010i01.09

\title{
STUDY OF PHYSICO-CHEMICAL PARAMETERS OF THE WATER CHIKLIYA POND DISTRICT BARWANI M.P.
}

\section{Mr.Heeralal Barde', Dr.Meenakshi Solanki²}

(1) Research Scholar, Dr. A. P. J. Abdul Kalam University, Indore, Madhya Pradesh, India.

(2) Professor \& Supervision Dr. A. P. J. Abdul Kalam University, Indore, Madhya Pradesh, India.

\begin{abstract}
All life living is the source of water. It nourishes aquatic life and rich diversity of plants and animals. Water is a major requirement for industrial and human survival development. Since ancient times, fresh water has always been of immense importance to the people, as its beginnings were his early habitations were within easy reach of settlements, rivers, dams, tanks, ponds and lakes. The utmost importance of fresh water resources has gained immense importance in their conservation.(1)The Air temperature of Chikliya Pond ranged between $28^{\circ} \mathrm{C}$ to $30.5^{\circ} \mathrm{C}$ during both Five month of study period. The Water temperature $23.5^{\circ} \mathrm{C}$ to $30^{\circ} \mathrm{C}$, Transparency $12 \mathrm{~cm}$. to $21 \mathrm{~cm}$. $\mathrm{pH} 7.1$ to 8.2 Alkalinity $83 \mathrm{mg} / \mathrm{lit}$. to 268 $\mathrm{mg} / \mathrm{lit}$.
\end{abstract}

Key Word : Limnological Condition ,Physico-Chemical Parameters temperature, $\mathrm{pH}$ Chikliya Pond. 
Introduction :

The existence of water is an important role for all living organisms. Water is the basic and primary requirement of all life's important processes and life originated first in water itself. Since then, humans have been fully connected to water since prehistoric times. We find this evidence historically. For example, to find settlements on the banks of rivers and to establish industries, and water is the basis of life. Singh at (2006) (2) In present time Water is the first requirement for the existence of life. The unbridled exploitation of water for irrigation, drinking and industrial purpose has caused a drastic decline of the important water resources. Physico-chemical analysis of an aquatic system indicates the water quality of that aquatic ecosystem. A number of workers from India and different parts of the world have made great contribution in the field of limnology for a long time.(3)

\section{Material and methods:-}

Chikliya pond is permanent pond in the present study. This Pond is situated at Chikliya village. This is located on "Barwani Silawad" road about $35 \mathrm{~km}$ away from the Barwani town. The geographical position of the pond is 21058' $30^{\prime \prime}$ latitude and $74^{\circ} 44^{\prime} 00^{\prime \prime}$ longitude. Water was analysed by standard mathods as descried by APHA (4)
(1995 and 1998): Trivedi and Goel (1986): (5) Welch (1953) (6),. The period of investigation was five month July 2020November 2020

Temperature:-The temperature was recorded with the help of simple; mercury filled Celsius thermometer having the accuracy of $0.1^{\circ} \mathrm{C}$ and range of $0^{\circ} \mathrm{C}$ to $50^{\circ} \mathrm{C}$ air and water temperature were taken with the help of this thermometer.

\section{Transparency:-}

Transparency was measured by a standard such disc of $20 \mathrm{~cm}$ diameter. The sub surface disappearance of the disc was measured twice and recorded as Secchi disc transparency in $\mathrm{cm}$

\section{Hydrogen ion concentration $(\mathrm{pH})$ :-}

The $\mathrm{pH}$ of the pond water was measured by systronix battery operated $\mathrm{pH}$ meter. The $\mathrm{pH}$ meter was earlier calibrated against standard buffer solution of $7.0 \mathrm{pH}$ and $9.2 \mathrm{pH}$ buffers.

\section{Alkalinity:-}

It was analysed titrimetrically with the help of sulphuric acid $(0.02 N)$, using phenolphthalein and methyl orange as indicators. Carbonate and bicarbonate were calculated by the methods as give by APHA (1998). 


\section{Calculation}

$\mathrm{ml}$ of titrant $\mathrm{p} \times 1000$

Phenolphthalein alkalinity (PT) as $\mathrm{mg} / \mathrm{lit} \mathrm{CaCO}_{3}=$

$\mathrm{ml}$ of sample.

$\mathrm{ml}$ of titrant $\mathrm{T} \times 1000$

Total alkalinity (TA) as $\mathrm{mg} / \mathrm{lit} \mathrm{CaCO}_{3}=$

$\mathrm{ml}$ of sample.

\section{Observation:-}

Monthly fluctuation in physico-chemical parameters of the Chikliya Pond (2020)

\begin{tabular}{|c|l|r|r|r|r|c|}
\hline S.N. & Parameter & Jul. & Aug. & Sep. & Oct. & Nov. \\
\hline 1 & Air temperature & 29 & 29.5 & 30 & 30.5 & 28 \\
\hline 2 & Water temperature & 25 & 26 & 29.5 & 30 & 23.5 \\
\hline 3 & Transparency & 20 & 12 & 17 & 19 & 21 \\
\hline 4 & pH & 7.2 & 7.1 & 7.6 & 8.1 & 8.2 \\
\hline 5 & Alkalinity & 98 & 123 & 83 & 91 & 168 \\
\hline
\end{tabular}




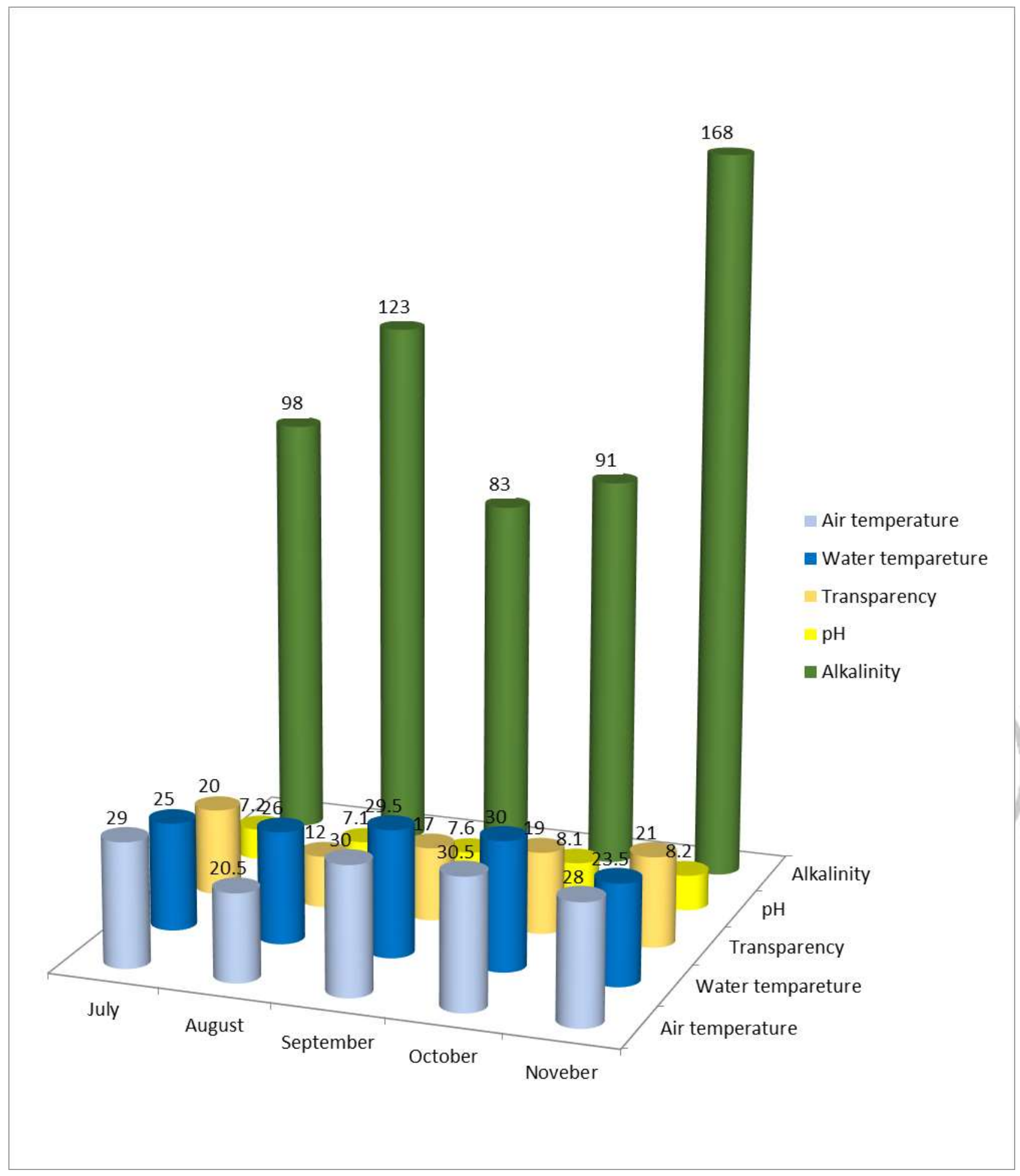

Fig-Monthly fluctuation in physico-chemical parameters graph of the chikliya pond. 
Results and Discussion:-

\section{Air temperature: -}

Air temperature of Chikliya pond ranged between $28^{\circ} \mathrm{C}$ to $30.5^{\circ} \mathrm{C}$ during both five month of study period. The minimum $\left(28^{\circ} \mathrm{C}\right)$ air temperature was observed in November and maximum $\left(30.5^{\circ} \mathrm{C}\right)$ was noticed during October. In pond of West Nimar values are comparatively more when compared to other Indian ponds. Singh et al.(1989), Choubey (1990), (7) Rehan et al. (1995). Mahajan \& Kanhere 1995) (8) worked on lakes, reservoirs and pond in this part of the country and reported the similar range of water temperature in their studies on Bhopal lake Yashwant Sagar reservoir, Tawa reservoir, Gandhi Sagar reservoir respectively.

\section{Water temperature: -}

The water temperature of Chikliya pond ranged between $25^{\circ} \mathrm{C}$ to $30^{\circ} \mathrm{C}$. The minimum $\left(25^{\circ} \mathrm{C}\right)$ temperature was recorded in the month July and maximum $\left(30^{\circ} \mathrm{C}\right)$ temperature was noticed during October.

\section{Transparency :-}

The Transparency of Chikliya pond ranged between $12 \mathrm{~cm}$. to $21 \mathrm{~cm}$. The minimum $(12 \mathrm{~cm})$ transparency was recorded in the month of July while the maximum $(21 \mathrm{~cm}$.$) in November.$ Bhatnagar (1984) and Saha (9) \& Choudhary (1985) reported minimum transparency in colder months and miximum transparency in monsoon in lower Lake of Bhopal.

$\mathrm{pH}:-$
The $\mathrm{pH}$ of Chikliya pond varied from 7.1 to 8.2 The minimum $\mathrm{pH}$ (7.1) was recorded in the month of August while the maximum (8.2) was noticed during November. Mahajan and Kanhere (1995)) reported an annual $\mathrm{pH}$ variation range of 7.2 to 8.4 in a subtropical pond and Dhobdiya pond.(10), Singh and Rai (1988) reported $\mathrm{pH}$ range of 6.5 to 7.9 in Talab, Chindwara.

\section{Alkalinity: -}

The alkalinity of Chikliya pond ranged between $83 \mathrm{mg} / \mathrm{lit}$, to $168 \mathrm{mg} / \mathrm{lit}$. The minimum (83 $\mathrm{mg} / \mathrm{lit}$ ) alkalinity was recorded during September and the maximum (168 mg/lit.) was observed in the month of November. Singh and Rai (1988) reported a range of $81 \mathrm{mg} / \mathrm{lit}$ to 113 $\mathrm{mg} / \mathrm{lit}$.in Badat Talab. Mahajan and Kanhere (1995) reported a range of 87 $\mathrm{mg} / 1$ to $115 \mathrm{mg} / \mathrm{lit}$.in Dhobdiya pond. (10)

\section{Conclusion: -}

Water is an important component of various kinds of fauna, plants and human life on earth. And by studying the physicochemical functions of water, it shows that the water is drinkable, and the aquatic animals are capable of rearing. The water purity test is done through various parameters, and water quality is determined.

\section{Reference:-}

[1] Saroj Mahajan"* and Dilip Billore2, Seasonal varivation and Assessment of water Quality of Nagehoon pond of khandwa District(M.P.) India, An International Research Journal of Environmental Science. ISSN: 0973- 4929, online ISSN: 2320-8031 ( 2014)., 
[2] Singh: J.P. Singh, S. and Khanna ,D.R. Water Quality Status of river Ganga in respect of physico-chemical, Microbial Characteristics at Anupshahar District Buland (U.P.) (2006).

(3) Sharma Dushyant Kumar and Uchchariya Rakhi Studies on physicochemical parameters of Pagara Reservoir, Joura, district Morena (M.P.) Value: 5.62 IJFAS 2019; 7(1): 293-298 (C) 2019 IJFAS

(4) AWWA and WPCF (1998). Standard methods for examination of water and waste water. 20th . Ed. American bublic Heaith Assoc. Washington, D.C.

(5) Trivedy, R.K. and P.G. Goel (1986). Chemical and biological methods for water pollution studies. Environmental publication, karad.

(6) Welch, (1953), Limnological methods: McGraw Hill Book Co. New York.-29. (2003)

(7) Chaubay, U. (1990). Studies on physicochemical and biological parameters
Gandhisagar reservoir Mandsaur District (M.P.); Ph.D. Thesis, Vikram University, Ujjain.

(8) Rehan, A.H., Khan, S.S. and Khan, M.R. \{1995\}. An ecological study a polluted pond containing abundant phytoplankton; Acta Ecol., 17 (1): 53-59.

(9) Bhatnagar, G.P. (1984). Limnology of lower Lake of Bhopal with special references to sewage pollution and eutrophication, Technical report M.A.B. Programe Deptt. Of Environ. Govt. of India, New Delhi: 1-77.

(10) Mahajan, A. and Kanhere (1995). Variation in primary productivity of a fresh water pond in West Nimar \{M.P.); Acta Ecol., 17 (2): 92-101. 